\title{
Tingkat Kepuasan Konsumen Terhadap Kualitas Pelayanan Apotek di Kabupaten Purwakarta Selama Pandemi Covid 19
}

\author{
Lina Aliyani Mardiana*, Dedy Frianto, Maya Arfania \\ Farmasi, Fakultas Farmasi, Universitas Buana Perjuangan Karawang, Jawa Barat, Indonesia

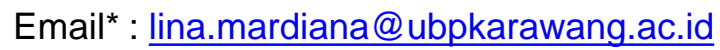

(Submit 19/12/2021, Revisi 20/12/2021, Diterima 30/12/2021, Terbit 31/12/2021)

\begin{abstract}
Abstrak
Kepuasan konsumen bukan hal yang sederhana, karena berkaitan dengan perspektif pelaku konsumen(1), yaitu perspektif pengambilan keputusan, pengalaman dan pengaruh perilaku(2), yang ke semuanya cenderung dinamis. Apotek atau sentra bisnis lain yang visioner senantiasa memperhatikan kepuasan konsumen dengan melakukan survey terhadap konsumen secara berkesinambungan agar memperoleh manfaat kinerja pendapatan atau keuntungan jangka panjang, terhadap produsen berbiaya rendah, manfaat ekonomis, reduksi sensitivitas harga, kunci sukses bisnis masa depan, dan word-of-mouth relationship ${ }^{(3)}$. Penelitian memiliki tujuan untuk mengetahui tingkat kepuasan konsumen terhadap kualitas pelayanan apotek di kabupaten Purwakarta Jawa Barat selama pandemi Covid-19, sehingga diketahui seberapa besar persentase lima dimensi kualitas pelayanan, juga persentase tingkat interpretasi konsumen terhadap kualitas pelayanan apotek di kabupaten Purwakarta tersebut. Metode penelitian dilakukan dengan cara penyebaran kuesioner menggunakan google formulir lewat grup whatsapp. responsden pada penelitian ini berjumlah 60 orang, teknik pengambilan sampel dengan nonprobability sampling, menggunakan metode accidental sampling. Berdasarkan hasil penelitian, pengukuran lima dimensi kualitas pelayanan apotek di kabupaten Purwakarta, diperoleh persentase rata-rata dari dimensi bukti langsung (tangibles) 45,43\%, keandalan (reability) 52,80\%, ketanggapan (responssiveness) 55,83\%, jaminan (assurance) 50,00\%, dan perhatian (empathy) $52,53 \%$. Kualitas pelayanan apotek yang meliputi 5 dimensi kualitas pelayanan, dengan nilai tertinggi pada dimensi ketanggapan (responssiveness) 55,83\%, dan nilai terendah pada dimensi bukti langsung (tangibles) 45,43\%.serta persentase tingkat interpretasi kualitas pelayanan apotek di kabupaten Purwakarta selama pandemi covid-19 sebesar $41 \%$ - 60\%, yaitu masuk ke dalam kategori sedang, dengan nilai rata-rata kelima dimensi $51,32 \%$.
\end{abstract}

Kata kunci: Covid 19, Kepuasan Konsumen, Kualitas Pelayanan 


\section{Pendahuluan}

Pada masa pandemi covid-19 ini, salah satu tempat yang dicari dan dikunjungi masyarakat adalah apotek. Di apotek tersedia perbekalan farmasi, seperti obat, alat kesehatan dan lain-lain yang sangat dibutuhkan untuk menunjang kesehatan, baik bagi masyarakat yang sudah terpapar covid-19 untuk dapat membeli obat sesuai resep dokter ataupun bagi masyarakat yang tidak terpapar untuk bisa membeli suplemen yang dapat meningkatkan daya tahan tubuh.

Perlu dilakukan survey di berbagai wilayah kota di Indonesia terhadap tempat-tempat yang sering dikunjungi oleh masyarakat, untuk dapat memberikan hasil pelayanan yang memuaskan atau bahkan sangat memuaskan sebagai salah satu wujud kepedulian sosial terhadap masyarakat. Untuk itu Peneliti melakukan survey di salah satu kota di Indonesia yaitu di kabupaten Purwakarta, Jawa Barat.

Kualitas pelayanan apotek di masa pandemi covid-19 memiliki pengaruh terhadap sisi psikologis konsumen yang bisa berpengaruh terhadap kesehatan. Di samping itu kualitas pelayanan yang baik akan memberikan kepuasan terhadap konsumen sehingga akan menaikan citra apotek itu sendiri, citra dari Pemerintah Daerah setempat khususnya Dinas Kesehatan Kabupaten Purwakarta sebagai Pembina apotek berkaitan dengan pengelolaan terhadap pelayanan publik di wilayahnya.

Kepuasan konsumen ada yang bersifat fungsional yakni kepuasan terhadap produk yang dijual, dan kepuasan psikologikal yakni kepuasan terhadap sesuatu yang tidak berwujud, seperti pelayan yang menyenangkan, mau mendengarkan keluhan dan lainlain ${ }^{(4)}$. Kepuasan konsumen itu sendiri menurut howard dan Sheth dalam Fandy Tjiptono merupakan penilaian konsumen setelah melakukan pembelian terhadap produk atau jasa, dengan membandingkan pengorbanan baik biaya dan lainya yang telah dilakukan. Jika konsumen merasa sepadan apa yang diperoleh maka akan menimbulkan kepuasan konsumen dan sebaliknya jika tidak sepadan maka akan menimbulkan ketidakpuasan (5).

Menurut Fandy Tjiptono, kualitas pelayanan bersifat dinamis yang berkaitan dengan produk, jasa, sumber daya manusia, juga proses dan lingkungan yang bisa memenuhi atau melebihi keinginan atau harapan konsumen (6). Dimensi kualitas pelayanan meliputi lima (5) dimensi yaitu TERRA. Tangibles, dimensi kualitas pelayanan yang bersifat konkret, dapat dilihat dan dirasakan secara langsung oleh konsumen, Emphaty, yaitu dimensi kualitas pelayanan berupa perhatian yang tulus dan dekat dengan konsumen, reliability, yaitu dimensi kualitas pelayanan yang bersifat abstrak, berhubungan dengan harapan konsumen, responssiveness, yaitu dimensi kualitas pelayanan berupa pemberian respons atau tanggapan yang positif terhadap semua keinginan dan kebutuhan konsumen, Assurance, yaitu dimensi kualitas pelayanan yang berkaitan dengan kepastian atau jaminan yang didapat oleh konsumen, seperti pemahaman product knowledge yang baik dari perusahaan (7). 


\section{Metode}

Penelitian ini dilakukan dengan cara mengirim kuesioner berupa google formulir ke grup whatsapp yang ada di data Base peneliti, kemudian data yang diperoleh ditabulasikan dan dianalsisa menggunakan aplikasi SPSS 22. Objek penelitian ini adalah masyarakat masyarakat Kabupaten Purwakarta yang pernah berbelanja di apotek wilayah Kabupaten Purwakarta, dengan kriteria berusia lebih dari 20 tahun. Penelitian ini dilakukan selama 3 bulan (April 2021-Juni 2021).

\section{Alat}

Survey dilakukan menggunakan Handphone dan Laptop untuk penyebaran kuesioner dan mengolah data serta software SPSS

\section{Bahan}

Dalam penelitian ini kuesioner dibuat dengan aplikasi Google formulir

\section{Prosedur Rinci}

Jumlah populasi yang tidak diketahui, yaitu konsumen apotek di wilayah kabupaten Purwakarta, sehingga untuk menentukan jumlah sampel sebagai partisipan kuesioner menggunakan teori Roscoe ${ }^{(8)}$, yaitu:

$n=(\mathrm{Vx}+\mathrm{Vy}) \times 10$

Keterangan:

$n$ = Ukuran sampel

$\mathrm{Vx}=$ Jumlah variabel $\mathrm{X}$ (5 dimensi kualitas yakni tangible, reability, responssiveness, assurance, empathy)

$\mathrm{Vy}=$ Jumlah variabel $\mathrm{Y}$ (Kepuasan konsumen $=1$

Diperoleh jumlah sampel :

$n=(5+1) \times 10=60$ sampel

Sampel diambil dengan teknik nonprobability sampling, karena elemen tidak diketahui(9), menggunakan metode accidental sampling, menurut Sugiyono (2017) yakni metode penentuan sampel berdasarkan kebetulan, siapa saja yang secara kebetulan/insidental bertemu dengan peneliti bisa digunakan sebagai sampel, bila orang yang kebetulan ditemui cocok sebagai sumber data ${ }^{(8)}$. Peneliti mengirimkan kuesioner berupa google formulir kepada grup whatsapp.

Jawaban hasil kuesioner dihitung persentase nya dengan rumus Riduwan (2015) (10) :

presentase $=\frac{\text { Total skor } x 100 \%}{\text { Skor maksimal }}$ 
Skor maksimal $=\frac{\text { Skor tertinggi }}{\text { Jumlah responden }}$

Kriteria Interpretasi dilihat di Tabel $1^{(9)}$.

Tabel 1 Kriteria Interpretasi

\begin{tabular}{cc}
\hline Skor Angka (\%) & Interpretasi \\
\hline $0-20$ & Sangat rendah \\
$21-40$ & Rendah \\
$41-60$ & Sedang \\
$61-80$ & Tinggi \\
$81-100$ & Sangat Tinggi \\
\hline
\end{tabular}

\section{Hasil}

\section{Karakteristik Sampel Penelitian}

Identitas responsden berdasarkan jenis kelamin, umur, tingkat pendidikan, wilayah tempat tinggal responsden, durasi kunjungan dan wilayah apotek yang dikunjungi responsden ter data dalam Tabel 2, diperoleh data, responsden terbanyak adalah perempuan sejumlah $63,3 \%$ (38 orang), sedangkan responsden laki-laki $36,7 \%$ (22 orang). Usia responsden terbanyak adalah responsden rentang usia 41-50 tahun sejumlah $61,7 \%$ (37 orang), sedangkan responsden dengan jumlah sedikit 3,7\% (2 orang) yaitu rentang usia 20-30 tahun, dan responsden lain nya memiliki persentase $21,7 \%$ (13 orang) untuk rentang usia 31-40 tahun, 13,3\% (8 orang) untuk rentang usis lebih dari 50 tahun. Tingkat pendidikan, responsden terbanyak memiliki tingkat pendidikan S1/S2 yaitu 46,7\% (28 orang), diikuti dengan tingkat pendidikan SMA yaitu $40 \%$ (24 orang), dan pendidikan lain nya (tidak sekolah dan pendidikan pesantren) sejumlah $13,3 \%$ (8 orang), sedangkan Pendidikan tingkat SD dan SMP 0\%. Tempat tinggal responsden terbanyak adalah di kecamatan Purwakarta 78,3\% (47), diikuti dengan kecamatan Babakan cikao 11,7\% (7 orang), Bungur sari 5\% (3 orang) dan Jatiluhur $3,3 \%$ (2 orang) serta Sukatani $1,7 \%$ (1 orang). Apotek yag dikunjungi responsden terbanyak adalah apotek yag berlokasi di kecamatan Purwakarta sejumlah $90 \%$ (54 orang), diikuti dengan apotek di wilayah Babakan cikao 5\% (3 orang), Bungursari 3,3\% (2 orang) dan Jatiluhur 1,7\% (1 orang). Dari data, bisa terlihat bahwa ada beberapa responsden yang lebih cenderung berkunjung ke apotek kecamatan Purwakarta dibandingkan dengan kecamatan tempat responsden tinggal. Ada kemungkinan responsden setelah berobat ke RSUD kabupaten Purwakarta atau RS swasta lain nya di kabupaten Purwakarta yang berlokasi di kecamatan Purwakarta, langsung mencari obat yang dibutuhkan di apotek sekitar kecamatan Purwakarta, atau responsden yang memiliki kepentingan ke kecamatan Purwakarta karena berkumpulnya sentra bisnis di kecamatan Purwakarta, sekaligus mencari apotek yang berlokasi di kecamatan Purwakarta untuk memenuhi kebutuhan obat dan lain-lain. Durasi kunjungan responsden ke apotek selama covid-19 ternyata jarang sejumlah $46,7 \%$ (28), diikuti dengan responsden yang cukup sering sejumlah $38,3 \%$ (23 orang), sementara 
yang sering berkunjung ke apotek $13,3 \%$ (8 orang) dan sangat sering hanya 1,7\% (1 orang). Meskipun demikian kalau dijumlah persentase cukup sering, sering dan sangat sering dan dibandingkan dengan jarang, maka persentase kunjungan responsden berkunjung ke apotek menjadi tinggi yaitu sejumlah 53,3\% (32 orang).

Tabel 2 Kriteria responsden

\begin{tabular}{cccccc}
\hline Jenis Kelamin & Jumlah & Presentase (\%) & Usia (Tahun) & Jumlah & Presentase \\
\hline Laki-laki & 22 & 36,7 & $20-30$ & 2 & 3,7 \\
Perempuan & 38 & 63,3 & $31-40$ & 13 & 21,7 \\
Total & 60 & 100,0 & $41-50$ & 37 & 61,7 \\
& & & $>50$ & 8 & 13,3 \\
& & & Total & 60 & 100,0 \\
\hline Tingkat & Jumlah & Presentase & Kecamatan & Jumlah & Presentase \\
Pendidikan & & & (Tempat & & \\
& & & Tinggal) & & \\
SD & 0 & 0 & B.Cikao & 7 & 11,7 \\
SMP & 0 & 0 & Bungursari & 3 & 5,0 \\
SMA & 24 & 40,0 & Jatiluhur & 2 & 3,3 \\
S1/S2 & 28 & 46,7 & Sukatani & 1 & 1,7 \\
Yang lain nya & 8 & 13,3 & Purwakarta & 47 & 10,3 \\
Total & 60 & 100 & Total & 60 & 100,0 \\
\hline Kecamatan & Jumlah & Presentase & Durasi & Jumlah & Presentase \\
(Apotek) & & Kunjungan & & 1,7 \\
\hline B.Cikao & 3 & 5,0 & Sangat sering & 1 & 13,3 \\
Bungursari & 2 & 3,3 & Sering & 8 & 37,3 \\
Jatiluhur & 1 & 1,7 & Cukup Sering & 23 & 46,7 \\
Purwakarta & 54 & 90,0 & Jarang & 28 & 100,0 \\
Total & 60 & 100,0 & Total & 60 &
\end{tabular}

Hasil kepuasan konsumen secara keseluruhan dapat dilihat pada Tabel 3, diperoleh data, dimensi konkret, bukti langsung (Tangibles) 45,43\%, dimensi kualitas pelayanan paling rendah dibanding empat dimensi kualitas pelayanan lain nya. Pada dimensi tangibles ini, kualitas pelayanan tertinggi pada ketersediaan tempat parkir yaitu 51,7\% dan terendah pada produk yang dijual lengkap dan mudah dicari yaitu $40 \%$. Untuk dimensi abstrak, keandalan (Reability) $52,8 \%$, dengan kualitas pelayanan tertinggi pada pernyataan kemampuan karyawan apotek memberikan pelayanan terbaik kepada konsumen yaitu $55 \%$. Dimensi berikutnya yaitu respons atau ketanggapan (responssiveness) $55,83 \%$, dimensi kualitas pelayanan tertinggi dibanding empat dimensi lain nya, persentase tertinggi pada pernyataan dimensi responssiveness ini yaitu pemberian informasi yang jelas oleh karyawan apotek sebesar $58,3 \%$. Selanjutnya dimensi jaminan atau kepastian (Assurance) $50 \%$, pernyataan persentase tertinggi berkaitan dengan keamanan konsumen terjamin selama berbelanja di apotek sejumlah $55 \%$. Dan dimensi terakhir yaitu perhatian (Empathy) $52,53 \%$, dengan persentase tertinggi yaitu pernyataan berkaian dengan pemahaman karyawan apotek akan keluhan konsumen serta pengetahuan karyawan apotek terhadap keinginan dan kebutuhan konsumen sejumah $56,7 \%$. 
Tabel 3 Rekapitulasi Jawaban dari Pernyataan-pernyataan pada setiap Dimensi Kualitas Pelayanan

\begin{tabular}{|c|c|c|c|c|c|c|c|}
\hline \multirow[t]{3}{*}{ No } & \multirow{3}{*}{$\begin{array}{l}\text { Indikator } \\
\text { Bukti Langsung (Tangibles) }\end{array}$} & \multicolumn{5}{|c|}{ Jumlah } & \multirow[t]{3}{*}{ Tota } \\
\hline & & \multirow[t]{2}{*}{ TP } & \multirow[t]{2}{*}{ KP } & \multirow{2}{*}{$\mathrm{CP}$} & \multirow[t]{2}{*}{$\mathbf{P}$} & \multirow[t]{2}{*}{ SP } & \\
\hline & & & & & & & \\
\hline 1 & $\begin{array}{l}\text { Apotek yang Saudara kunjungi mudah } \\
\text { dijangkau }\end{array}$ & 0 & 0 & 28 & 27 & 5 & 60 \\
\hline 2 & Apotek yang Saudara kunjungi tersedia tempat parkir & 0 & 8 & 31 & 16 & 5 & 60 \\
\hline 3 & Karyawan Apotek berpenampilan dengan rapi & 0 & 4 & 26 & 23 & 7 & 60 \\
\hline \multirow[t]{2}{*}{4} & $\begin{array}{l}\text { Produk di Apotek dijual lengkap dan mudah } \\
\text { ditemukan }\end{array}$ & 0 & 12 & 24 & 21 & 3 & 60 \\
\hline & Keandalan (Reability) & & & & & & \\
\hline 1 & $\begin{array}{l}\text { Kecepatan dan ketelitian karyawan kasir Apotek } \\
\text { dalam melayani konsumen }\end{array}$ & 0 & 3 & 31 & 19 & 7 & 60 \\
\hline 2 & $\begin{array}{l}\text { Karyawan Apotek mempunyai kemampuan untuk } \\
\text { memberikan pelayanan yang baik kepada semua } \\
\text { konsumen }\end{array}$ & 0 & 5 & 33 & 16 & 6 & 60 \\
\hline \multirow[t]{2}{*}{3} & $\begin{array}{l}\text { Karyawan Apotek tepat dalam memecahkan } \\
\text { atau memberi solusi terhadap masalah } \\
\text { konsumen }\end{array}$ & 0 & 7 & 31 & 16 & 6 & 60 \\
\hline & Ketanggapan (responssiveness) & & & & & & \\
\hline 1 & $\begin{array}{l}\text { Ketanggapan karyawan Apotek dalam melayani } \\
\text { keinginan konsumen }\end{array}$ & 0 & 4 & 33 & 17 & 6 & 60 \\
\hline 2 & $\begin{array}{l}\text { Pemberian informasi yang jelas oleh } \\
\text { karyawan Apotek }\end{array}$ & 0 & 6 & 35 & 14 & 5 & 60 \\
\hline 3 & $\begin{array}{l}\text { Kecepatan karyawan Apotek dalam } \\
\text { melayani/menyiapkan/menemukan produk yang dicari } \\
\text { konsumen }\end{array}$ & 0 & 4 & 32 & 18 & 6 & 60 \\
\hline 4 & $\begin{array}{l}\text { Kesediaan karyawan Apotek untuk mendengarkan } \\
\text { keluhan dari konsumen }\end{array}$ & 0 & 6 & 34 & 15 & 5 & 60 \\
\hline \multicolumn{8}{|c|}{ Jaminan (Assurance) } \\
\hline 1 & $\begin{array}{l}\text { Keamanan konsumen terjamin selamaberbelanja } \\
\text { di Apotek }\end{array}$ & 0 & 1 & 33 & 21 & 5 & 60 \\
\hline 2 & $\begin{array}{l}\text { Produk yang dijual di Apotek terjamin mutu } \\
\text { dan kualitas serta keasliannya }\end{array}$ & 0 & 2 & 25 & 27 & 6 & 60 \\
\hline 3 & $\begin{array}{l}\text { Karyawan Apotek berlaku ramah dan sopan } \\
\text { santun kepada konsumen }\end{array}$ & 0 & 3 & 30 & 21 & 6 & 60 \\
\hline \multicolumn{8}{|c|}{ Perhatian (Empathy) } \\
\hline 1 & $\begin{array}{l}\text { Karyawan Apotek dapat berkomunikasi dengan baik } \\
\text { dengan para konsumen }\end{array}$ & 0 & 5 & 31 & 19 & 5 & 60 \\
\hline 2 & $\begin{array}{l}\text { Waktu operasional (jam buka) Apotek yang nyaman } \\
\text { dan aman bagi konsumen }\end{array}$ & 0 & 3 & 24 & 27 & 6 & 60 \\
\hline 3 & $\begin{array}{l}\text { Pemahaman karyawan Apotek akan keluhan } \\
\text { konsumen }\end{array}$ & 0 & 5 & 34 & 17 & 4 & 60 \\
\hline 4 & $\begin{array}{l}\text { Karyawan Apotek mempunyai pengetahuan terhadap } \\
\text { kebutuhan dan keinginan konsumen }\end{array}$ & 0 & 5 & 34 & 17 & 4 & 60 \\
\hline
\end{tabular}

Ket : $\mathrm{TP}=$ Tidak Puas $\mathrm{KP}=$ Kurang Puas $\mathrm{CP}=$ Cukup Puas $\mathrm{P}=\mathrm{Puas} \mathrm{SP}=$ Sangat Puas 


\section{Kesimpulan}

Berdasarkan hasil survey kepuasan konsumen terhadap kualitas pelayanan apotek di wilayah kabupaten Purwakarta selama masa pandemi covid-19, diperoleh data dengan nilai kepuasan konsumen sedang dengan presentase nilai rata-rata $51,32 \%$. Kualitas pelayanan tertinggi pada dimensi responssiveness $55,83 \%$ dan terendah pada dimensi tangibles $45,43 \%$.

Saran penelitian kedepannya dilakukan penelitian menggali lebih jauh kebutuhan konsumen terhadap pelayanan di apotek, sehingga apa yang dibutuhkan bisa terpenuhi. Dilakukan penelitian untuk wilayah-wilayah lain nya di Indonesia. Dilakukan penelitian membandingkan perilaku konsumen tiap wilayah di Indonesia bahkan di luar negeri.

\section{Daftar Pustaka}

1. Tjiptono, F and Gregorius Chandra, 2017, Variabel yang mempengaruhi kepuasan konsumen, Yogyakarta

2. Mowen, John C dan Minor, Micheal, 2012, Perilaku Konsumen dialihbahasakan oleh Dwi Kartika yahya, Erlangga, Jakarta

3. Ali Hasan, 2013, Marketing dan Kasus-Kasus Pilihan, CAPS, Yogyakarta

4. Ety Sufiyanti.,A. Jalaludin Sayutu.,Ayu Oka Windarti, 2017, Tingkat Kepuasan Konsumen Terhadap Kualitas Pelayanan Minimarket, Jurnal Riset Bisnis dan Investasi Vol. 3 No. 1 April 2017, Politeknik Negeri Sriwijaya, Indonesia.

5. Tjiptono, Fandy, 2014, Pemasaran Jasa-Prinsip, Penerapan, dan Penelitian, Andi Offset, Yogyakarta

6. Tjiptono, F, 2012, Manajemen Jasa, ANDI, Yogyakarta.

7. Lupiyoadi, R., 2014, Manajemen Pemasaran Jasa, Salemba Empat, Jakarta.

8. Sugiyono, 2017, Metode Penelitian Kuantitatif Kualitatif $R \& D$, Alfabeta, Bandung.

9. https://www.idntimes.com/science/experiment/izza-namira-1/macam-tekniksampling

10. Riduwan, 2015, Dasar-Dasar Statistika, Alfabeta, Bandung. 